\title{
DEVELOPMENT OF COMIC MEDIA ON VIRUS MATERIALS FOR HIGH SCHOOL CLASS STUDENTS
}

\author{
Fitri Yati Kumil Laila'), Eva Nurul Malahayati2), Marinda Sari Sofiyana ${ }^{3}$ \\ 1,2 Islamic University of Balitar; Jl. Majapahit No.04, Telp. (0342) 813145 \\ ${ }^{3}$ Biology education, FKIP Islamic University of Balitar, Blitar \\ e-mail: ${ }^{* 1}$ Fitriatikumil@gmail.com
}

\begin{abstract}
The development was carried out aimed at finding out the feasibility of comic learning media in viral material for high school students of class $X$ This research is a Research and Development study using a 4-D model (Define, Design, Develop, and Disseminate) limited to the Develop stage. The data taken from this study is based on the validation of material experts, media experts, linguists, and readability tests. The results of the validation by the expert team get an average score of $84.64 \%$ with proper information. Student readability test results are $90 \%$ high category with very decent information. According to the results outlined in the comic learning media, it is worthy of being used as a learning media for viral material.
\end{abstract}

Keywords: Research Development, Media Comics

\section{INTRODUTIONS}

Learning is a process of interaction between students and educators and learning resources. The interaction created between students must be able to create an atmosphere that is interactive, inspiring, fun, challenging, and motivates students to actively participate. This is a goal that can be expected. The purpose of learning is to help students gain a variety of experiences, with that experience, students' behavior increases in both quantity and quality. One aspect that greatly influences learning is how a teacher delivers material. Especially in learning Natural Sciences (IPA) (Hamdani, 2011). Science learning conveys more theories and concepts, so that in the delivery of learning media it is necessary to make it easier for students to understand theories and concepts.

Learning media is something that can be used as a means of connecting to achieve messages in student learning activities. Good media will make students easy to understand the material. The selection of the right media is needed to support students understanding. The teacher must pay attention to material that is difficult for students to understand, so 
JOSAR, Vol. 1 No. 2 September, 2018; p-ISSN: 2502-8251; e-ISSN: 2503-1155

Copyrights@ Balitar Islamic University, Blitar-Indonesia https://ejournal.unisbablitar.ac.id/index.php/josar

students are able to understand a material. Sudjana and Rivai (2011) say that in the presence of learning media, the learning process will attract students' attention, thus improving student learning outcomes. Learning media include tools physically used to convey the contents of learning materials such as books, tape recorders, tapes, videos, cameras, films, slides, pictures, graphics, television, and computers.

The first step taken before the development of the media, namely observing the characteristics of students and material that is considered difficult by students. Observations were made by giving open questionnaires to 80 students in 4 schools. As many as $73.7 \%$ of students stated material in biology subjects that were difficult to understand, namely viruses. As many as $93.7 \%$ of students are interested if the teacher uses learning media as a support for understanding the material. Students are very interested and enthusiastic more actively, better understanding learning by using media. Students say that the desired learning media is media that is considered to facilitate students to understand the material, students tend to prefer and quickly understand learning media such as images.

Learning by looking at images makes it easy for students to understand and remember messages or information. Students are easier to remember things that have been seen by the eye than just hearing an explanation from the teacher without help from the picture. One way to overcome this is by presenting pictorial media that are presented in language in the classroom. Media comics is a book containing illustrated stories, the age of children so that adolescents tend to be more fond of reading comic stories than reading subject books. This is because comics have interesting images and contain stories. It is hoped that with the comic-based learning media developed in this study, later it can help students understand viral material easily. 
JOSAR, Vol. 1 No. 2 September, 2018; p-ISSN: 2502-8251; e-ISSN: 2503-1155

Copyrights@ Balitar Islamic University, Blitar-Indonesia https://ejournal.unisbablitar.ac.id/index.php/josar

The development of comic learning media is supported by research conducted by A'yun et al (2014), Jariah (2017), the results of the two studies said that comic media is worthy of being used as a learning media. These results indicate that the media developed is effectively used in the learning process. The purpose of the research was to find out the media feasibility of comic learning in virus material for class $\mathrm{X}$ high school.

\section{RESEARC METHODS}

The design of this study is research and development (Research and Development). The approach used is a qualitative approach and a quantitative approach. Quantitative data in the form of assessment scores from the expert team (material experts, media experts, linguists), qualitative data in the form of advice and input from the expert team. The development model used is a 4-D model developed by Thiagarajan et al 1978, which consists of the stages of define, design, and development without performing the disseminate stage.

The procedure of the study begins with the define stage, carried out to determine the needs in the field and the products needed by conducting a front end analysis, analysis of student characteristics, task analysis, concept analysis, and determinant learning objectives. The second stage is design, which is done by compiling tests, compiling the media, compiling the format, the initial design of the product. The third stage is development, this stage is a process to produce a product that is feasible to use through validation by a team of experts

Products that have been declared feasible by the expert team can be used for product testing. Product testing is done by readability, teacher response, and student response. The research instrument used was a questionnaire validation sheet by a team of experts, and student readability questionnaires, teacher responses, and student responses. The data analysis technique used in this study is qualitative data analysis 
JOSAR, Vol. 1 No. 2 September, 2018; p-ISSN: 2502-8251; e-ISSN: 2503-1155

Copyrights@ Balitar Islamic University, Blitar-Indonesia https://ejournal.unisbablitar.ac.id/index.php/josar

and quantitative data analysis. The results of the data analysis were then interpreted and concluded based on the assessment qualification criteria in Table 1 and 2.

Table 1. Criteria for validity and product revisions

\begin{tabular}{ccc}
\hline $\begin{array}{c}\text { Percentage (in } \\
\text { percent) }\end{array}$ & Level of Validity & Information \\
\hline $85-100$ & Very valid & Very Worthy \\
$70-84$ & Valid & Worthy \\
$65-69$ & Valid enough & Fair enough \\
$50-54$ & Less Valid & Not worth it \\
$0-49$ & Invalid & Not feasible \\
\hline
\end{tabular}

(Source: adapted from Purwanto in Ula, 2013)

Table 2. Criteria for student readability and response

\begin{tabular}{ccc}
\hline Percentage & Category & Information \\
\hline $85 \% \leq \mathrm{P}$ & High & Very Positive \\
$70 \% \leq \mathrm{P}<85 \%$ & Is being & Positive \\
$50 \% \leq \mathrm{P}<70 \%$ & Enough & Less Positive \\
$\mathrm{P}<50 \%$ & Low & Not Positive \\
\hline
\end{tabular}

(Source: adapted from Purwanto in Ula, 2013)

\section{RESULTS AND DISCUSSION}

The define stage is carried out to find out the front end analysis, analysis of student characteristics, task analysis, concept analysis, and determinant learning objectives. The analysis was carried out as the basis for developing media products that were in accordance with the needs. The front end analysis is conducted to find out the curriculum applied in the school. curriculum that has been applied in schools, namely the 2013 curriculum. The results of student analysis show that the characteristics of students. Task analysis is adjusted to $\mathrm{KI}$ and KD. Formulation of learning objectives to establish the basis needed in the development of learning media. Development of learning media must be in accordance with the basic competencies achieved by students. Based on these basic competencies indicators and learning objectives will be formulated.

The design phase is designing the design of the initial design of the product which was developed in the form of comic learning media on viral 
JOSAR, Vol. 1 No. 2 September, 2018; p-ISSN: 2502-8251; e-ISSN: 2503-1155

Copyrights@ Balitar Islamic University, Blitar-Indonesia https://ejournal.unisbablitar.ac.id/index.php/josar

material for high school students of class $\mathrm{X}$. This type of media comic is science fiction, designed using Hybrid techniques. The choice of background on the media is adjusted to the storyline, a combination of images and information accordingly. This comic media is also designed with a combination of full color, so it looks attractive.

The development stage is the development stage that produces products, namely biological comics. The media of biology comics has been validated by material experts, media experts, linguists, and student readability tests. Expert assessment of comic-shaped learning media aims to determine the feasibility of learning media for class $X$ high school students. The results of material expert validation can be seen in Table 3 .

Table 3. Assessment of material experts

\begin{tabular}{llccc}
\hline No & \multicolumn{1}{c}{ Description } & \multicolumn{3}{c}{ Score } \\
\hline \multicolumn{1}{l}{ Material Aspects } & Validator 1 & Validator 2 & Validator 3 \\
\hline 3 & 30 & 27 & 30 \\
$\quad \begin{array}{l}\text { Compatibility of } \\
\text { Material with Design }\end{array}$ & 32 & 30 & 35 \\
\hline Total score & & 184 \\
\hline Percentage of average scores of Material Experts & $81,7 \%$ \\
\hline Category & Worthy \\
\hline
\end{tabular}

The assessment of material experts is $81.7 \%$, so comic learning media in terms of material aspects are suitable to be used as media. The material in the comic media is complete and in accordance with the media. The storyline in the media is in accordance with the level of difficulty in the material. The material in comic media is also presented with applications in everyday life, making it easier for students to understand material. The second assessment was carried out by 3 media experts. It can be seen in Table 4. 
JOSAR, Vol. 1 No. 2 September, 2018; p-ISSN: 2502-8251; e-ISSN: 2503-1155

Copyrights@ Balitar Islamic University, Blitar-Indonesia https://ejournal.unisbablitar.ac.id/index.php/josar

Table 4. Assessment of media experts

\begin{tabular}{|c|c|c|c|c|}
\hline \multirow[t]{2}{*}{ No } & \multirow[t]{2}{*}{ Description } & \multicolumn{3}{|c|}{ Score } \\
\hline & & Validator 1 & Validator 2 & Validator 3 \\
\hline 1 & Cover Design & 13 & 15 & 15 \\
\hline 2 & Image Clarity & 23 & 28 & 27 \\
\hline 3 & $\begin{array}{l}\text { Conformity to the } \\
\text { Format of Writing, and } \\
\text { Typography }\end{array}$ & 28 & 35 & 34 \\
\hline & l score & & & 218 \\
\hline & entage of average scor & S of Media E & perts & $90,83 \%$ \\
\hline & gory & & & Very Worthy \\
\hline
\end{tabular}

The presentation component gets a percentage of $90.83 \%$ with a very decent category. Based on the media comic eligibility criteria in the virus material has been declared feasible. This comic media is completely compiled with supporting images about virus material. In the comic media there is an illustration of the storyline that fits the material. Illustrations in this media are very important to support the attractiveness of media loading, to attract students' attention. The third assessment was carried out by 3 linguists as can be seen in Table 5 .

\section{Table 5. Assessment of linguists}

\begin{tabular}{|c|c|c|c|c|}
\hline No & Description & & Score & \\
\hline & & Validator 1 & Validator 2 & Validator 3 \\
\hline 1 & Language & & & \\
\hline & $\begin{array}{l}\text { Compatibility and Use } \\
\text { of Terms }\end{array}$ & 28 & 28 & 30 \\
\hline 2 & Typography & 12 & 12 & 12 \\
\hline Tot & score & & & 122 \\
\hline Per & entage of average scor & of Linguists & & $81,33 \%$ \\
\hline Cat & gory & & & Worthy \\
\hline
\end{tabular}

The assessment of linguists got a score of $81.33 \%$ in the feasible category. The language used in the media is in accordance with the eligibility requirements. The language for explanation in comic media is adjusted to the level of student development. The language used can be easily digested by students in understanding material. After going through 
JOSAR, Vol. 1 No. 2 September, 2018; p-ISSN: 2502-8251; e-ISSN: 2503-1155

Copyrights@ Balitar Islamic University, Blitar-Indonesia https://ejournal.unisbablitar.ac.id/index.php/josar

the assessment stage by the next media experts, namely readability test, teacher response assessment, and student response. The assessment can be seen in Table 6 .

Table 6. Assessment of readability tests

\begin{tabular}{llccccc}
\hline No & Description & \multicolumn{5}{c}{ Score } \\
\hline & $\begin{array}{c}\text { Students } \\
1\end{array}$ & $\begin{array}{c}\text { Students } \\
2\end{array}$ & $\begin{array}{c}\text { Students } \\
3\end{array}$ & $\begin{array}{c}\text { Students } \\
4\end{array}$ & $\begin{array}{c}\text { Students } \\
5\end{array}$ \\
\hline 1 & $\begin{array}{l}\text { Graphic } \\
\text { design }\end{array}$ & 10 & 9 & 10 & 9 & 10 \\
\hline 2 & $\begin{array}{l}\text { Language } \\
\text { aspects }\end{array}$ & 19 & 19 & 19 & 19 & 18 \\
\hline $2 \begin{array}{l}\text { Coverage } \\
\text { of Material }\end{array}$ & 17 & 19 & 19 & 20 & 18 \\
\hline Total score & & & & & 235 \\
\hline Average score percentage & & & & $90 \%$ \\
\hline Category & & & & Very positive \\
\hline
\end{tabular}

Based on the assessment of the readability test of $90 \%$ included in the very positive category, so it can be said that the media is very feasible to use. The design used attracts student's attention, the suitability of illustrations and images is good. Language aspects are used according to the level of student development, making it easier for students to understand the material. The scope of the material in the media is complete and in accordance with the media. The storyline in the media is in accordance with the level of difficulty in the material. Assessment of teacher responses and student responses can be seen in Tables 7 and 8

\section{Table 7. Teacher response}

\begin{tabular}{clcc}
\hline No & Description & \multicolumn{2}{c}{ Score } \\
\hline \multicolumn{1}{c}{ Material Aspects } & Student 1 & Student 2 \\
\hline 1 & 75 & 66 \\
\hline 2 & Media Aspects & 50 & 46 \\
\hline 3 & Language aspects & 73 & 67 \\
\hline Total I score & 377 \\
\hline Percentage of average scores of Material Experts & $92 \%$ \\
\hline \multicolumn{2}{l}{ Category } & Very Worthy \\
\hline
\end{tabular}


JOSAR, Vol. 1 No. 2 September, 2018; p-ISSN: 2502-8251; e-ISSN: 2503-1155

Copyrights@ Balitar Islamic University, Blitar-Indonesia https://ejournal.unisbablitar.ac.id/index.php/josar

Table 8. Student responses

\begin{tabular}{lll}
\hline No $\begin{array}{l}\text { The number } \\
\text { of students }\end{array}$ & $\begin{array}{l}\text { Description } \\
\text { Positive aspects of } \\
\text { comic media }\end{array}$ & $\begin{array}{l}\text { Negative aspects of comic } \\
\text { media }\end{array}$ \\
\hline
\end{tabular}

\begin{tabular}{lcc}
\hline 1 & 754 & 717 \\
\hline Total score & 1471 \\
\hline Average score percentage & $84,05 \%$ \\
\hline Category & Positive \\
\hline \multicolumn{2}{c}{ The teacher's response results were } & $92 \%$, thus \\
\hline
\end{tabular}

comic media was very suitable for use in the learning process. The results of student responses were $84.05 \%$ in the positive category. The comic media on this viral material gets a positive response from students seen from the concept of making comics, story lines and examples of material images that are easy to understand, a combination of interesting illustrations and colors, so that students can attract the attention of comic media on viral material that is. The results of the validation of the experts above are in accordance with the research conducted by Evriyani et al (2016) entitled "Development of Concept Map-Based Comics As Learning Media In Nervous System Materials In High School" resulting in decent media products with scores of material experts $92.6 \%$, experts media $86.6 \%$, and teacher perceptions $85.5 \%$ with good interpretations.

\section{CONCLUSIONS}

Based on the development research that has been carried out by material experts, media experts and linguists get an average score of $84.64 \%$, the teacher response results are $92 \%$, and student responses are $84.05 \%$, so it can be concluded that comic learning media on the material the virus is suitable for use in Biology science learning class $X$ high school. 
JOSAR, Vol. 1 No. 2 September, 2018; p-ISSN: 2502-8251; e-ISSN: 2503-1155

Copyrights@ Balitar Islamic University, Blitar-Indonesia https://ejournal.unisbablitar.ac.id/index.php/josar

\section{Suggestion}

Suggestions that can be given is that the researcher should do further development research in the next material. Researchers are also advised to conduct research development until the disseminate stage.

\section{REFRENCES}

A'yun Q, Abdurrahman, Maharta N. 2015. Development of comic-based bulletin learning media scientific approach in integrated science learning. Physics Learning Journal. 3 (4): 115-125

Evriyani, Rusdi, Indraswary. 2016 Development of comic-based concept maps as learning media in nervous system material in high school. Journal of Biology Education (BIOSFERJPB). 9(2): 14-42.

Fawaidah H, Sukarmin. 2016. Media Development Chemic (Chemistry Comic) As a Learning Media in Chemistry Bond Materials for Class X High School Students. Unesa Journal of Chemical Education. 5(3): 621-628.

Hamdani. 2011. Teaching Learning Strategy. Bandung: Pustaka Setia

Jariah. 2017. Development of comic-based learning media in the material of blood clotting process in class XI MA MANDIRI. Essay. Tarbiyah Faculty and Makassar UIN Alauddin Teacher Training.Sudjana, Rivai. 2013. Teaching media. Bandung: Printing Sinar Baru Algensindo Offset.

Sugiyono. 2016. Quantitative, Qualitative, and RnD Research Methods. Bandung: ALFABETA.Thiagarajan S, Semmel DS, Semmel MI. 1974. Intructional Developmen for Training Teachers of Exceptional Children. Indiana: Indiana University Bloomington.

NH Ula, Sa'dijah C. 2013. Development of mathematical LKS uses problem solving strategies around the material around and the circle of class VIII in semester II of SMP. Journal of Malang State University. 1 (3): 1-9. 